\section{Commentary: Laudable but incremental improvements ahead of a sea change}

\author{
David S. Winlaw, MBBS, MD, FRACS
}

Many of our more complex operations involve a right ventricle-to-pulmonary artery (RV-PA) connection. This fundamental component of our repertoire is associated with highly variable and frankly disappointing outcomes. We have normalized the expectation of poor outcomes as we work the limitations of current solutions. In the context of a neonatal intervention, replacement of an RV-PA connection and its future impact on child and family is understandably minimized, but we know that adolescents and adults stress about the tube that is "failing" inside them. Whilst we offer "safe" replacement, the pathway remains problematic.

It is valuable to understand baseline outcomes of current practice. In this report, ${ }^{1}$ a noncontemporaneous comparison of RV-PA connections was made, contrasting pulmonary and aortic homografts with femoral venous conduits. As usual in our field, there is profound case heterogeneity that can't easily be controlled for; the quality of pulmonary arteries, distal pulmonary artery pressures, heterotopic versus orthtotopic lie of the conduit and surgeon-specific technical factors. "Time to replacement" is an objective and easily measurable end point, but it says nothing about the preceding and concurrent processes of valve dysfunction and size mismatch between conduit and patient. Institutional guidelines determining indications for conduit replacement are provided, but there are no patient-specific or objective measurements determining time to replacement beyond simple echocardiographic assessment. We don't

From the Heart Institute, Cardiothoracic Surgery, Cincinnati Children's Hospital Medical Center, Cincinnati, Ohio.

Disclosures: The author reported no conflicts of interest.

The Journal policy requires editors and reviewers to disclose conflicts of interest and to decline handling or reviewing manuscripts for which they may have a conflict of interest. The editors and reviewers of this article have no conflicts of interest.

Received for publication Aug 30, 2020; revisions received Aug 30, 2020; accepted for publication Sept 11, 2020; available ahead of print Oct 20, 2020.

Address for reprints: David S. Winlaw, MBBS, MD, FRACS, Cincinnati Children's Hospital Medical Center, Heart Institute, Cardiothoracic Surgery, 3333 Burnet Ave, MLC2013, Cincinnati, OH 45229-3026 (E-mail: david.winlaw@ cchmc.org). JTCVS Open 2020;4:68-9

2666-2736

Copyright (C) 2020 The Authors. Published by Elsevier Inc. on behalf of The American Association for Thoracic Surgery. This is an open access article under the CC BY-NCND license (http://creativecommons.org/licenses/by-nc-nd/4.0/).

https://doi.org/10.1016/j.xjon.2020.09.004

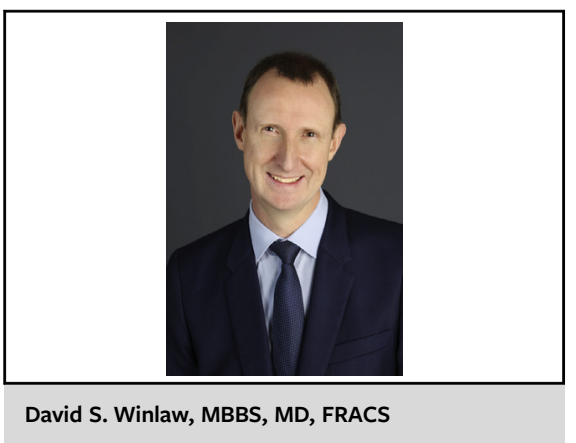

CENTRAL MESSAGE

Femoral venous conduits offer some advantages in the right ventricle-to-pulmonary artery position with few downsides. New technologies are needed to improve on current allo- and xenogenic offerings.

know what proportion of time patients experience freedom from both stenosis and regurgitation.

The headline is that the femoral venous conduit is noninferior to homografts. In this regard, it is a useful follow-up to earlier reports demonstrating their application. ${ }^{2}$ The reduced cost and greater availability of the femoral venous conduit are additional benefits. The freedom from endocarditis stands in contrast to reports of the other available nonhomograft choice, the bovine jugular vein conduit. ${ }^{3}$ Femoral vein conduits may well have an incremental benefit over homograft tissues. Their ovoid shape and low profile might better suit construction of heterotopic pathways between the right ventricle, sternum anteriorly, and posteriorly positioned pulmonary arteries.

To address the bigger issue, it is now time to gather prospective data on patients with RV-PA conduits to objectively compare early, midterm, and late patterns of "failure." This should include assessments of stenosis, regurgitation, right ventricular work, and energy loss across the conduit. Whilst we hope and expect that surgically revised conduits are free of obstruction, early competence of homograft valves in particular can be disappointing. Catheter-based technology (valve supported by stent) may well be superior to standard surgical approaches.

New classes of biomaterial used for both conduit and valve are in development and in some cases in clinical trials. These include early human experience in congenital patients (Xeltis 
technology, ${ }^{4,5}$ ) as well as in adult acquired valvular disease (Foldax valve, ClinicalTrials.gov Identifier: NCT03851068 ${ }^{6}$ ). These hold the promise of non-immunogenic material with avoidance of both allo- and xeno-antigens. Customization of valve design and personalization ${ }^{7}$ of implanted conduit remain opportunities to address deficiencies in the clinical pathway for those with an RV conduit. It is time for greater expectations.

\section{References}

1. Sinha L, Mota L, Ozturk M, Staffa SJ, Zurakowski D, Jonas RA, et al. Cryopreserved valved femoral vein homografts for right ventricular outflow tract reconstruction in infants. J Thorac Cardiovasc Surg Open. 2020;4:58-65.

2. Schiller O, Sinha P, Zurakowski D, Jonas RA. Reconstruction of right ventricular outflow tract in neonates and infants using valved cryopreserved femoral vein homografts. J Thorac Cardiovasc Surg. 2014;147:874-9.
3. Beckerman Z, León LE, Zea-Vera R, Mery CM, Fraser CD. High incidence of late infective endocarditis in bovine jugular vein valved conduits. J Thorac Cardiovasc Surg. 2018;156:728-34.e2.

4. Soliman O, Miyazaki Y, Abdelghani M, Brugmans M, Witsenburg M, Onuma Y, et al. Midterm performance of a novel restorative pulmonary valved conduit: preclinical results. EuroIntervention. 2017;13:e1418-27.

5. Bennink G, Mroczek T, Sivalingam S, Prodan Z, Herrington C, Bacha E, et al. A novel pulmonary valve homing device-early feasibility Study (EFS-US) and first in man (FIM-EU/Asia) $1 \& 2$ year results. In: International Conference of Tissue Engineered Heart Valves. 2020. Available at: https://ictehv.com/program. Accessed August 30, 2020.

6. Dandeniyage LS, Adhikari R, Bown M, Shanks R, Adhikari B, Easton CD, et al Morphology and surface properties of high strength siloxane poly(urethaneurea)s developed for heart valve application. J Biomed Mater Res B. 2019; 107:112-21.

7. Ebrahimi P, Youssef D, Salve G, Ayer J, Dehghani F, Fletcher DF, et al. Evaluation of personalized right ventricle to pulmonary artery conduits using in silico design and computational analysis of flow. J Thorac Cardiovasc Surg Open. 2020;1:33-48. 